\title{
3
}

\section{The travails of current macroeconomic and exchange rate management}

\author{
Wing Thye Woo
}

The quandary in macroeconomic management that the Chinese government is currently facing cannot be seen more clearly than in the following two newspaper headlines. On 18 August 2003, an article in Singapore's Straits Times under the headline 'Hu calls for more work creation as jobless rate rises' reported that the Secretary-General of the Chinese Communist Party, Hu Jin Tao, had called for 'stronger measures... [including] fiscal subsidies, tax incentives, insurance subsidies and credit opportunities' to spur economic growth. On 19 August 2003, Hong Kong's South China Morning Post carried an article with the headline 'Investments soar amid reluctance to rein in growth', reporting that the Chairman of the State Development and Reform Commission, Ma Kai, had 'urged the nation to be wary of overheating and unveiled measures to cut back lending at state-run banks.'

Have China's recent macroeconomic policies been too cautious? Or have they been too inflationary? Evidence in favour of the first assessment can be found in the successive negative inflation rates since 1997, and continued weak aggregate demand is suggested by the -0.4 per cent inflation rate in the first half of 2003. The case for overheating is based on the following facts: first, the GDP growth rate in the first quarter of 2003 was 8.9 per cent; second, fiscal and monetary stimuli were greatly ramped up in the March-June period to offset the negative consequences of 
SARS 2 ; third, the price index for intermediate input has risen by five per cent since the beginning of 2003; and, fourth, inflation has traditionally lagged behind excessive growth by $9-12$ months.

The cost of erring on the conservative side is certainly a high one. The official growth target of seven per cent in 2003 could only create 10 million new urban jobs, while there are 24 million urban job-seekers. ${ }^{3}$ In addition, 150 million of China's 500 million rural workers are 'effectively' unemployed-and this is the most conservative estimate. ${ }^{4}$ The cost of overheating could also be very big because high inflation in the past has sometimes undermined social stability. Furthermore, overheating is often a sign that the state credit system has been undermining economic restructuring objectives by bailing out inefficient state enterprises and funding investments in sectors with excess capacity.

As if China's macroeconomic managers were not already sufficiently vexed by the confusing signals of 'overheating' and 'below-potential growth', they now face tremendous political pressures from Japan, Western Europe and the United States to substantially revalue the renminbi (RMB). ${ }^{5}$ The current indignation over an undervalued RMB was set off on 1 December 2002 when two senior officials of Japan's Ministry of Finance wrote in the Financial Times that 'China is exporting deflation...through export growth and a combination of price deflation and an exchange rate pegged to the dollar', and asked China 'to allow the currency to appreciate' (Kuroda and Kawai 2002). This call to mobilise international opinion for action on the RMB appears to have succeeded. By mid 2003, South Korea, Western Europe and the United States had joined Japan in urging an appreciation of the RMB, probably in response to the adamant charges levied by their domestic industries about unfair competition from cheap Chinese imports. ${ }^{6}$ How China will respond to this foreign clamour for RMB revaluation will, not surprisingly, depend on its diagnosis of the current macroeconomic situation. The Chinese leaders are more likely to agree quickly to making the RMB much more expensive if they are convinced that the economy is overheated, and unlikely to go beyond the immediate introduction of a minor trading band around the current RMB-US dollar exchange rate if they conclude that deflation is a more plausible threat to China's economic growth.

In assessing the two contradictory desired stances of macroeconomic policies, the relevant analytical issue for an economist is whether China is already at its 'natural' rate of unemployment. An output growth rate that pushes the actual 
unemployment rate above the natural unemployment rate would not be unsustainable but would also risk generating a high inflation rate. The point is that, at any given moment, there is a maximum value on the sustainable output growth rate that is determined by the existing material and institutional conditions of the economy (and of the outside world). Thus, unless the higher growth rate desired by the policymaker is below the 'natural' growth rate, more expansionary macroeconomic policies will not deliver the desired higher growth rate.

The operational difficulty for macroeconomic management is that the natural growth rate of an economy is not immutable. For example, a rise in the rate of technological innovation would increase the natural growth rate, while the steady convergence of a formerly autarkic developing country to the frontier of modern science would cause a steady decline in the natural growth rate. Because of the latter phenomenon of growth slowdown as a consequence of economic maturation, it is not so straightforward to claim that China's annualised growth rate of 8.2 per cent in the first half of 2003 is below the natural output growth rate despite two crucial facts. The first fact is that the 2003 growth rate is more than a percentage point below the 9.4 per cent average growth rate of the 1979-2002 period; the second is that the inflation rate of -0.4 per cent in the first half of 2003 is substantially below the 5.5 per cent average of the 1979-2002 period. ${ }^{7}$ One needs a more compelling argument against the alternative explanation that the lower 2003 growth rate simply reflects a lower natural output growth rate and that slightly negative inflation is compatible with being on the natural growth path.

While it is important to manipulate aggregate demand via monetary and fiscal policies to keep the actual unemployment rate close to the natural unemployment rate, fortunately China is a position to implement other economic policies that will move the natural unemployment rate downward-that is, increase the natural output growth rate. To use a production analogy, the biggest gain comes not only from keeping an engine running at peak efficiency but also from having the engine with the largest capacity. The most important economic task for China is to adopt the best economic growth engine that world economic history has identified-a market economy where competitive private enterprises constitute the norm, and where the state focuses mainly on the provision of public goods and social insurance. The case for making this type of market economy the new growth engine is obvious 
when one recognises that China's remarkable growth in the post 1978 period has come from deregulation that has allowed Chinese economic institutions to converge with those of private market economies, especially those of the East Asian variety. ${ }^{8}$

My second argument is that many of the major macroeconomic challenges facing the Chinese government have their roots in China's inadequate marketisation and continued discrimination against the domestic private sector. Because of bureaucratic incentives within the state-controlled banks which monopolise the financial system, the large volume of savings is inefficiently intermediated into investment (with the private component of investment particularly deprived of bank loans). The significant consequence of inadequate intermediation is a level of aggregate demand that expands slower than the natural output growth rate. The state has thereby responded to deflationary tendencies by undertaking massive public investment to soak up excess savings in the banks. While increased public-directed investment can be a satisfactory solution in the short run, it is a disaster in the long run. The point is that an efficient banking system is an indispensable component of the new growth engine that China needs to put in place.

My third argument is that China's persistent trade surplus is fundamentally linked to the deflation phenomenon, and successful solution of one will mean successful solution of the other. A chronic trade surplus means that national savings are chronically larger than domestic investments, which is exactly the malaise of inadequate financial intermediation. An alternative to revaluing the RMB would therefore be increasing the level of domestic investment, especially targeting investment projects that require large amounts of imported capital equipment. It is hard to over-emphasise that it is extremely anomalous for a developing economy like China to be exporting capital to the rest of the world the counterpart of a current account surplus. Something must be fundamentally flawed when capital-short China is investing abroad in the same way as capital-abundant Japan.

My fourth argument is that the state-owned sector and state-controlled companies are still a serious threat to sustained high growth, banking sector solvency, and price stability. Worse yet, corruption within state enterprises undermines social stability. The switch to the new growth engine necessitates continued privatisation of non defence-related state enterprises that are not natural monopolies, and the elimination of legal discrimination against private sector activities. 


\section{A SLOWER GROWTH PHASE, AND ATTEMPTS AT MACROECONOMIC STIMULATION}

Towards the end of the 1990s, the partially reformed Chinese economy entered a slower growth phase, having largely exhausted the growth potential created by significant economic deregulation and internationalisation (Table 1.1). The average annual growth rate in the 1997-2002 period was 9.4 per cent, and growth rates from 1997-2002 were below 9.4 per cent. This extended period of below-average growth was unprecedented in the market reform period. When I compared mean growth rates for 1979-96 (9.9 per cent) with mean growth rates for 1997-2002 (7.8 per cent), I found the difference between them to be statistically significant. The tstatistic is 2.52 .

The analytically difficult question is whether lower growth rates for 1997-2002 reflect inadequate growth in aggregate demand or a reduction in the growth potential of aggregate supply. The fact that there was a statistically significant downward shift in the inflation rate between the two subperiods-the t-statistic is 5.6-with price changes negative for 1997-2002, raises the possibility that inadequate demand contributed to the lower growth rates in the second subperiod. This implication follows because, in the absence of a drop in aggregate demand growth, a fall in supply growth would have produced an outcome of lower growth-cum-higher inflation (that is, stagflation) rather than the observed outcome of lower growth-cum-deflation. The evidence suggests that the natural output growth rate at present is likely to be higher than 7.8 per cent.

The explanation for the lower growth-cum-deflation phenomenon for 1997-2002 is that there was not only a slowdown in supply-side growth but also a slowdown in aggregate demand growth. In the next section I will develop the argument that China's dysfunctional banking system has created a deflationary bias in the economy.

In thinking about the growth of aggregate supply there is little justification for the belief that there is a positive relationship between the actual growth rate and the inflation rate for all values of the growth rate. It is more likely that, if a positive relationship exists at all within any short period, it will be limited to a small range clustered around the natural growth rate-say, half a percentage point on each side of the natural growth rate. ${ }^{9}$ My estimate is that the natural output growth rate in 2003 , as permitted by China's material conditions and institutional structure, is 8 per cent. My estimate is higher than the 7.5 per cent in Huang (2003) and the official growth target of 7 per cent, and is at the high end of the 7-8 per cent range in $\mathrm{Yu}$ 
(2003). I also estimate that, in the absence of substantial reforms enabling the rapid emergence of a dynamic private sector, the natural growth rate will decline to 7.5 per cent at the end of the decade as the catching-up process proceeds further. If the necessary comprehensive reforms are implemented, however, the natural growth rate at the end of the decade will be 8.5 per cent.

The hypothesis that China has entered into a slower growth phase is consistent with employment data (Table 3.1). Average annual employment growth in the industrial sector was 2.8 per cent during the 1992-97 period, with a minimum of 2.1 per cent in 1997. Employment growth fell significantly after 1997-0.3 per cent in 1998, -1.1 per cent in 1999, -1.2 per cent in 2000, and 0.4 per cent in 2001. Employment in manufacturing had actually turned bad earlier in 1996. Manufacturing employment growth was negative throughout the 1996-2000 period, with a particularly large decline of 13.5 per cent in 1998.

Table 3.1 Employment in China's industries, 1978-2001

\begin{tabular}{|c|c|c|c|c|c|c|}
\hline \multirow[b]{4}{*}{1978} & \multirow{2}{*}{\multicolumn{2}{|c|}{$\begin{array}{c}\text { Employment level } \\
\text { Secondary Manufacturing }\end{array}$}} & \multirow{2}{*}{\multicolumn{2}{|c|}{$\begin{array}{l}\text { Employment share } \\
\text { Secondary Manufacturing }\end{array}$}} & \multirow{2}{*}{\multicolumn{2}{|c|}{$\begin{array}{l}\text { Growth in employment } \\
\text { Secondary Manufacturing }\end{array}$}} \\
\hline & & & & & & \\
\hline & \multicolumn{2}{|c|}{ (in millions) } & \multicolumn{2}{|c|}{ (percent of total employment) } & (percent per year) & $\begin{array}{l}\text { sector } \\
\text { er year) }\end{array}$ \\
\hline & 69.5 & 53.3 & 17.3 & 13.3 & & \\
\hline 1988 & 121.5 & 86.5 & 22.4 & 15.9 & $5.8^{*}$ & $5.0^{*}$ \\
\hline 1989 & 119.8 & 85.5 & 21.6 & 15.4 & -1.4 & -1.2 \\
\hline 1990 & 138.6 & 86.2 & 21.4 & 13.3 & 15.7 & 0.9 \\
\hline 1991 & 140.2 & 88.4 & 21.4 & 13.5 & 1.1 & 2.5 \\
\hline 1992 & 143.5 & 91.1 & 21.7 & 13.8 & 2.4 & 3.0 \\
\hline 1993 & 149.6 & 93.0 & 22.4 & 13.9 & 4.2 & 2.1 \\
\hline 1994 & 153.1 & 96.1 & 22.7 & 14.3 & 2.3 & 3.4 \\
\hline 1995 & 156.5 & 98.0 & 23.0 & 14.4 & 2.2 & 2.0 \\
\hline 1996 & 162.0 & 97.6 & 23.5 & 14.2 & 3.5 & -0.4 \\
\hline 1997 & 165.5 & 96.1 & 23.7 & 13.8 & 2.1 & -1.5 \\
\hline 1998 & 166.0 & 83.2 & 23.5 & 11.8 & 0.3 & -13.5 \\
\hline 1999 & 164.2 & 81.1 & 23.0 & 11.4 & -1.1 & -2.5 \\
\hline 2000 & 162.2 & 80.4 & 22.5 & 11.2 & -1.2 & -0.8 \\
\hline 2001 & 162.8 & 80.8 & 22.3 & 11.1 & 0.4 & 0.5 \\
\hline
\end{tabular}

Note: * Annual compound growth rate between 1978 and 1988.

Source: State Statistical Bureau, various years. Zhongguo Tongji Nianjian [China Statistical Yearbook], Zhongguo Tongji Chubanshe, Beijing. 1990-2001 data from 2002 edition, earlier data from 2001 edition. 2002 and 2003 GDP growth rates are from Citigroup, 2003. China Economics, Citigroup, 6 March. 
Price deflation appeared in the Retail Price Index (RPI) in October 1997, and in the Consumer Price Index (CPI) in February 1998. When it became apparent in the middle of 1998 that the economy was slowing significantly, the government implemented monetary and fiscal measures to boost aggregate demand (Figures 3.1 and 3.2, Table 3.2). Interest rates have been reduced eight times in less than six years, with the latest rate reduction on 21 February 2001, bringing the one-year deposit rate to 1.98 per cent and the one-year lending rate to 2.34 per cent (Figure 3.1). However, financial growth rates followed a declining trend in 2001. The central bank then began not only to increase reserves more aggressively but also to lean even more on the state banks to extend credit.

The annualised (year-on-year) growth rate of fixed asset investment of the state sector was kept above 15 per cent from July 1998 to July 1999, then lowered as exports to the other East Asian economics recovered (Figure 3.2). Fiscal stimulus

Figure 3.1 Credit conditions (money growth and interest rates, per cent)

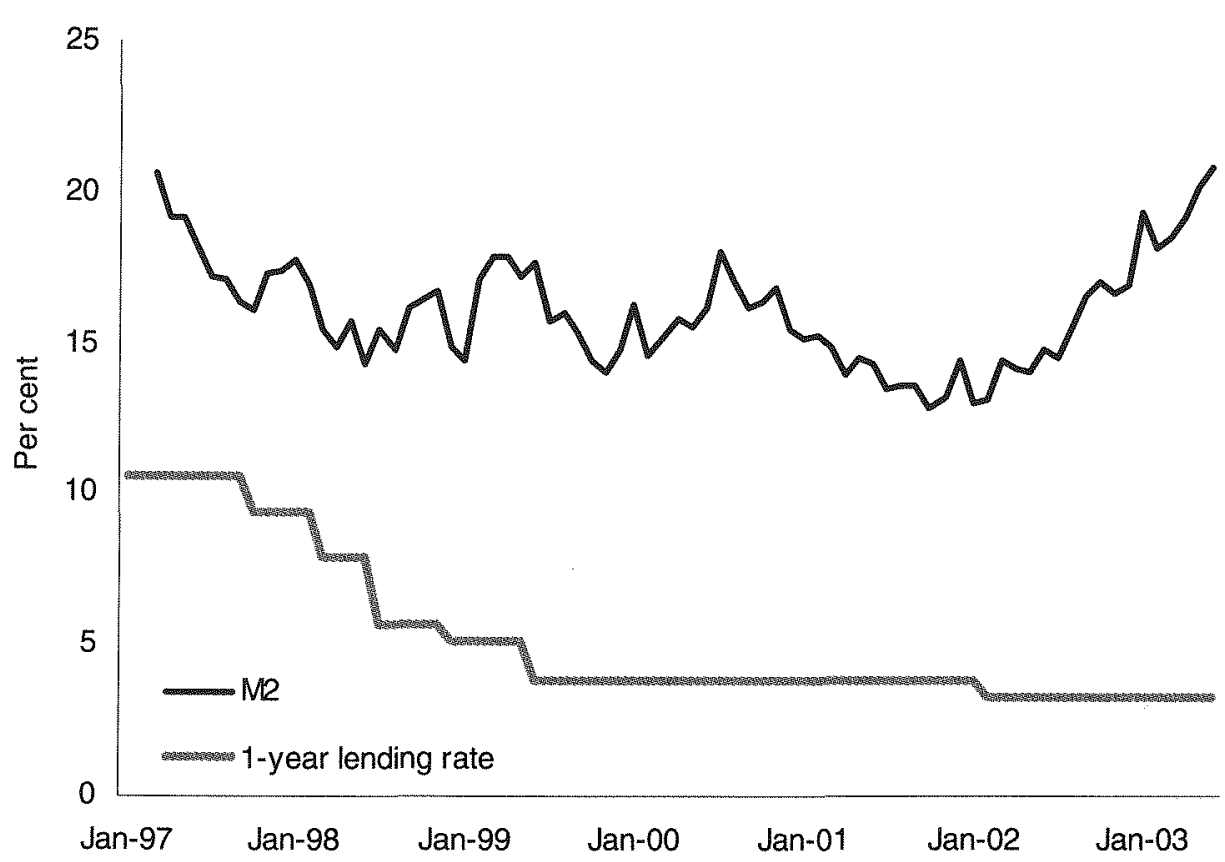

Source: Citicorp Database. 
was renewed in 2001. State spending on capital construction jumped from 209.5 billion yuan in 2000 to 251.8 billion yuan in 2001 , keeping the annualised growth rate of state sector fixed asset investment above 15 per cent for 11 of the 12 months in 2001. When the CPI slipped again into negative growth rates, (falling in November 2001 and reaching -1.3 per cent in April 2002), the Chinese government increased the intensity of the fiscal stimulus; for example, the growth rate of state sector fixed asset investment was above 23 per cent in the January 2002 - November 2002 period, and was 17 per cent in December 2002. Apart from investment in capital construction, the government also implemented several pay rises in this period. The increased government spending meant the fiscal deficit increased substantially from 1.1 per cent of GDP in 1998 to 1.9 per cent in 1999, 2.5 per cent in 2000, 2.7 per cent in 2001, and 2.9 per cent in 2002 (Table 3.2). ${ }^{10}$ Most government economists, for example Jia (2002), believe that investment funds raised through the issuing of treasury bonds contributed about 2 percentage points to GDP growth each year in the 1999-2002 period.

With the encouragement of the central bank, especially with the onset of SARS in early 2003 , the state banks greatly expanded their loans, especially to the real estate sector, and financial growth went from 16.8 per cent in the fourth quarter of 2002 to reach 20.0 per cent in the second quarter of 2003. Additional fiscal and monetary stimuli created to offset the deleterious effects of SARS on aggregate demand caused the rate of fixed asset investment to jump from 21.6 per cent in the fourth quarter of 2002 to 32.4 per cent in the first quarter of 2003 and 31.7 per cent in the second quarter of 2003 . The unfortunate feature about encouraging stateowned enterprise (SOE) investments, as emphasised by Fan and Woo (1996), is that, in a partially reformed centrally planned economy, there are many institutional features that motivate SOE investments to veer out of control and overheat the economy.

\section{THE DEFLATIONARY AND TRADE ACCOUNT CONSEQUENCES OF INADEQUATE FINANCIAL INTERMEDIATION}

At a superficial level, systemic deflationary pressures that have plagued China since 1997 have their sources in a shrinking money multiplier (a phenomenon that many Chinese economists have called 'the liquidity trap'), and a slowing down in the growth of consumption (a phenomenon commonly known as the paradox of 
Figure 3.2 Consumption and investment growth (year-on-year, per cent)

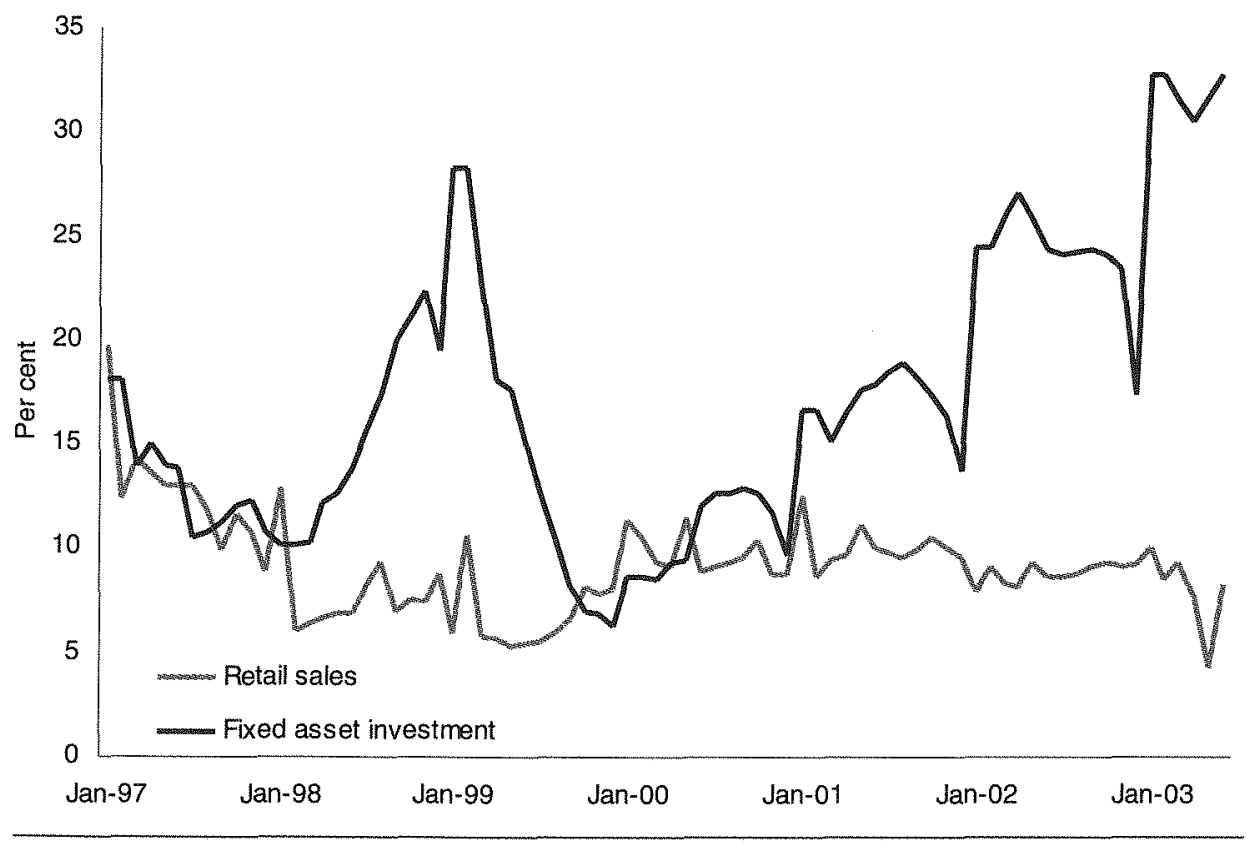

Source: Citicorp Database

Table 3.2 Growing fiscal spending

\begin{tabular}{lcccccc}
\hline & & & \multicolumn{3}{c}{ Spending } \\
Fiscal & $\begin{array}{c}\text { Fiscal } \\
\text { revenue } \\
\text { (RMB bn) }\end{array}$ & $\begin{array}{c}\text { Fiscal } \\
\text { (RMB bn) }\end{array}$ & $\begin{array}{c}\text { Share } \\
\text { (Ralance } \\
\text { of GDP }\end{array}$ & $\begin{array}{c}\text { (RM bn) } \\
\text { construction } \\
\text { (RMB bn) }\end{array}$ & $\begin{array}{c}\text { Share } \\
\text { of GDP } \\
(\%)\end{array}$ \\
1997 & 865.1 & 923.4 & -58.2 & -0.7 & 102.0 & 1.4 \\
1998 & 987.6 & 1079.8 & -92.2 & -1.1 & 138.8 & 1.8 \\
1999 & 1144.4 & 1318.8 & -174.4 & -1.9 & 211.7 & 2.6 \\
2000 & 1339.5 & 1588.7 & -249.1 & -2.5 & 209.5 & 2.4 \\
2001 & 1637.1 & 1884.4 & -247.3 & -2.7 & 251.8 & 2.6 \\
2002 & 1891.4 & 2201.2 & -309.8 & -2.9 & & \\
2003 & & & -319.8 & -2.8 & & \\
\hline
\end{tabular}

Source: Citigroup. 
thrift'). ${ }^{11}$ China has tried to boost the domestic economy with successive cuts in interest rates, but the rise in credit creation has been much lower than expected, except for the periods when the central bank has leaned heavily on the banks. ${ }^{12}$ The paradox of thritt refers to the low level of private aggregate demand due to increased private savings. The savings rate increased from almost 20 per cent of GDP in 1981 to 30 per cent in 1988 and almost 40 per cent in 2001.

At a deeper level, however, both these phenomena spring from the same causethe absence of adequate financial intermediation in China. The liquidity trap made its appearance in the mid 1990s when Zhu Rongji called for the removal of the state bank manager if the ratio of NPLs in her bank were to rise two years consecutively. As the majority of state enterprises are either in the red or just breaking even, the banks became unwilling to lend money to SOEs. Lending more to private enterprises was not really an option, however, since their legal status was lower than that of state enterprises and there was no reliable way to assess their balance sheets. The only activity to which the banks were happy to allocate their funds is the purchase of state bonds - that is, the financing of the government's deficit. ${ }^{13}$ The elimination of the liquidity trap requires the state to remove barriers to lending to the private sector, ending legal discrimination against private activities and establishing uniform accounting and auditing standards with credible enforcement mechanisms.

In discussions about the increasing savings rate, a common view is that it reflects uncertainty about the future. Many SOE workers feel this uncertainty in the face of widespread privatisation of loss-making SOEs. This explanation is incomplete, because there has also been a rise in the rural saving rate, even though rural residents have little to fear about the loss of jobs in the state-enterprise sector because none of them are employed there. On the basis of the work of Liu and Woo (1994) on savings behaviour, I conjecture that the desire to invest is an important reason for the rural sector's increased savings rate. The most dynamic industrial expansion in China during the period 1984-94 occurred in the rural areas. Since non-state firms in rural areas cannot borrow from the bank, the only way they could establish themselves was through self-financing, requiring would-be entrepreneurs to save first.

In the very first phase of rural industrialisation, the amount of capital needed to start a factory workshop was very small. After a decade of rapid industrial growth, the Chinese countryside is saturated with labour-intensive enterprises. As competition among rural enterprises is fierce at present, it no longer makes economic sense to 
invest and open the same type of factory workshop. Rural enterprises must therefore move up to the next stage of value-added production to be more profitable.

The new generation of rural enterprises is much more capital-intensive, thus it requires larger startup funds. Rural residents have responded to the higher capital requirements by increasing their savings. Since the phenomenon of investmentmotivated saving must also be present within the Chinese urban community, pessimism-based explanations for the rise in urban savings are only partially correct. In fact, with the steady relaxation of regulations against the establishment of private businesses in rural and urban areas, the amount of investment-motivated savings in China could only have risen more. According to Williamson's (1988) summing up of the historical record of Western Europe and North America, "investment demand seems to have been the driving force behind private saving and accumulation, past and present.'

Total fixed investment has increased spectacularly as a proportion of GDP, with annual averages of 28.8 per cent in 1984-88, 34.0 per cent in 1992-96 and 36.3 per cent in 1997-2001. SOE investment increased in 1992-96 (19.8 per cent), then returned to its initial 1984-88 level (18.7 per cent) (Table 3.3). However, the amount of state-directed investment in 1997-2001 could be more than three percentage points higher than 18.7 per cent of GDP, because many of the big SOEs of 1988 had by 1999 converted themselves (or components of themselves) to shareholding companies listed on the stock exchanges, while remaining state-controlled. Furthermore, many SOES have formed joint-venture firms with domestic and foreign companies, with themselves as the controlling shareholders.

In contrast to the spectacular rise in total investment and the probably equal rise in state-directed investment, rural investment has fallen from 8.2 per cent in 198488 to 7.7 per cent in 1992-96 and 7.5 per cent in 1997-2001. My hypothesis is that a major reason for the decline in the rural investment ratio is that the traditional labour-intensive factory is no longer profitable, and rural entrepreneurs have been unable to borrow the money to undertake the more capital-intensive investments required for the next generation of rural enterprises. ${ }^{14}$ The investment-GDP ratio rose at the national level because FDI rose while state investments (through the budget, SOEs and state-controlled enterprises) fully utilised higher domestic savings.

Inow turn to show that another outcome of inadequate financial intermediation is a chronic current account surplus. To see this point, consider the following accounting relationship: 
Current account surplus $=$ (government budget surplus)

+ (savings of SOEs - investments by SOEs)

+ (savings of the non-state sector - investments of the non-state sector). ${ }^{15}$

The facts for the recent period are that the current account surplus (or, loosely speaking, the trade surplus) is positive, the government budget surplus is negative at an unprecedented level, and SOE savings are less than SOE investments. This means that the savings of the non-state sector must greatly exceed the investments of the non-state sector. As documented earlier, the government has sought to fight

Table 3.3 Investment trends by ownership (per cent of GDP)

\begin{tabular}{lccc}
\hline & Total & Rural & SOE \\
1981 & 19.8 & 5.1 & 13.7 \\
1982 & 23.2 & 6.2 & 16.0 \\
1983 & 24.1 & 7.0 & 16.0 \\
1984 & 25.6 & 7.7 & 16.5 \\
1985 & 28.4 & 7.6 & 18.7 \\
1986 & 29.6 & 8.0 & 20.4 \\
1987 & 30.4 & 8.9 & 19.2 \\
1988 & 30.1 & 8.9 & 18.5 \\
June 4th Tian An Men disruption, $1989-91$ & & \\
1992 & 29.5 & 7.5 & 19.8 \\
1993 & 36.0 & 8.0 & 22.1 \\
1994 & 36.4 & 7.5 & 20.6 \\
1995 & 34.2 & 7.5 & 18.6 \\
1996 & 33.8 & 7.9 & 17.7 \\
1997 & 33.5 & 7.7 & 17.6 \\
1998 & 36.3 & 7.5 & 19.6 \\
1999 & 36.4 & 7.5 & 19.4 \\
2000 & 36.8 & 7.5 & 18.5 \\
2001 & 38.8 & 7.5 & 18.4 \\
Average 1984-88 & 28.8 & 8.2 & 18.7 \\
Average 1992-96 & 34.0 & 7.7 & 19.8 \\
Average 1997-2001 & 36.3 & 7.5 & 18.7 \\
\hline
\end{tabular}

Notes: Investment refers to fixed asset investment. 1984 was the year when the central government gave the clear signal that it had no ideological objection to the formation of rural enterprises. Rural $=$ rural collectives and rural individuals. SOE = state-owned units only, does not inciude state-controlled units listed as various types of joint-owned units (for example, shareholding units, joint-venture units).

Source: State Statistical Bureau, various years. Zhongguo Tongji Nianjian [China Statistical Yearbook], Zhongguo Tongji Chubanshe, Beijing. 
deflation by increasing public works (that is, running record budget deficits) and encouraging SOE investments to soak up the excess savings. The rise in total investments has not been sufficient to use up the excess savings, however, and these residual excess savings have leaked abroad in the form of an aggregate trade surplus. Inadequate financial intermediation has made China a capital-exporting country!

This perverse current account outcome is not new. Taiwan had exactly this problem up to the mid 1980s when all Taiwanese banks were state-owned and operated according to the civil service regulation that the loan officer had to repay any bad loan that he had approved. The result was a massive failure in financial intermediation that caused Taiwan's current account surplus to amount to 21 percent of GDP in 1986.

China's tendency to generate persistent current account surpluses manifested itself only after 1994 because of major policy changes implemented in that year. Before 1994, with the government budget deficit being usually small, the voracious absorption of bank loans by SOEs, in the soft-budget environment, to invest recklessly kept the current account usually negative. In 1994, Zhu Rongji implemented stricter controls on the state-owned banks (SOBs) to reduce the then 24 percent inflation rate and the explosion of NPLs. This lower growth rate in SOE investments from 1995 onward is the reason China's built-in propensity for current account surpluses revealed itself only from 1995 onward. This propensity is mainly caused by the secular rise in the savings of the non-state sector for the reasons identified earlier, for example, secular rise in the required amount of start-up capital, secular improvement in the official attitude toward market capitalism. ${ }^{16}$ China is not producing the gargantuan current account surpluses seen in Taiwan in the mid 1980 s because of its record budget deficit and still overly large amounts of SOE investments.

Obviously, increasing budget deficits and SOE investments to counter deflation and reduce the trade surplus can only be a satisfactory solution in the short run. In the long run, the increased public investments could follow an increasingly rentseeking path that is wasteful as in Japan (where, for example, a second big bridge would be built to a lowly populated island almost solely to benefit a politically connected construction company), and the increased SOE investments could convert themselves into non-performing loans at the SOBs.

The solution to the problem of excess saving is not for the government to absorb it by increasing its budget deficit but to establish an improved mechanism for 
coordinating private savings and private investment. This solution is correct regardless of my hypothesis about investment-motivated savings.

\section{THE BANKING SYSTEM AS A SINKHOLE}

Undeniably, China's banks are in serious financial straits. According to the People's Bank of China (PBOC), the proportion of NPLS of the four big SOBs is presently about 26 per cent, about 2 percentage points lower than a year ago. However, recent scandal over improper loans given to a Shanghai developer by the Hong Kong branch of the Bank of China suggests undiscovered problems. Citigroup (2002) suggests that NPLs amount to 35 per cent of outstanding loans to the four big SOBs at the beginning of 2002, and that the average capital adequacy ratio (CAR) of these four banks is 5.0 per cent (Table 3.4).

Bank reform efforts of the past several years have failed. The proportion of NPLS declined from its record high of 48 per cent in 1998 , but this reduction was achieved mainly by the transfer of NPLs to the state-owned asset management corporations (AMCs). Most NPLs still need to be dealt with and are the responsibility of the People's Bank of China or the Ministry of Finance. ${ }^{18}$ Worse still, most of the problematic SOEs remain the clients of the parent banks and continue to create new NPLs. New NPLs have been created by intermittent pressure on the banks from the government to expand investment credit to combat deflation, and to expand social stability loans to reduce firm closures. This may be an important reason for the deterioration in the quality of banking assets in recent years, causing the capital adequacy ratio to fall to 5 per cent in early 2002 from the more than 8 per cent in late 1998 after the recapitalisation of the banks.

Table 3.4 Rising fragility of China's banking sector

\begin{tabular}{lccc}
\hline & End-1996 & End-1998 & Beginning-2002 \\
Proportions of NPLs (\%) & & & \\
Big four banks & 40.0 & 48.0 & 35.0 \\
Ten joint-stock banks &.. & 13.5 & 15.5 \\
Average CAR (\%) & 4.4 & $>8.0$ & 5.0 \\
Big four banks & 4.4 & \\
\hline
\end{tabular}

Notes: CAR: capital adequacy ratio. Proportion of NPLs for the four major banks for 1996 and 1998 are re-estimated on the basis of new information made available at the beginning of 2001 . The proportion for 2001 excluded the Rmb1.4 trillion transferred to the AMCs in the previous year. Source: Citigroup, 2002. Greater China Insights, 14 June. 
However, it is possible that a large part of the post 1998 NPLs may actually be pre 1998 NPLs that were not recognised during the 1998 recapitalisation. At that time, the SOBs might not have wanted to reveal the actual NPL situation because this would have revealed previous official NPL estimates to have been wildly inaccurate. In any case, the state banks are now in need of another round of recapitalisation.

With such a fragile banking system, China has committed itself to opening up the banking system completely after five years of joining the WTO. Foreign banks have been able to conduct transactions in foreign currencies from the beginning of WTO membership (December 2001), conduct transactions with the local corporate sector in renminbi after two years, and conduct transactions with local households in local currencies after five years. Although foreign banks are likely to compete only in the coastal cities, the pressure on domestic banks would be great, as the big four banks extract about 95 per cent of their profits from about half a dozen coastal cities (Shanghai, Beijing, Xiamen, Shenzhen, Guangzhou, and Tianjin). Because there is no depositor insurance in China, the obvious question is whether depositors will believe that foreign banks cause SOBs to bankrupt, and rush to withdraw their savings from the SOBs, setting in motion the vicious downward spiral of credit contraction, leading to business failures, rendering sound financial institutions insolvent, and contracting credit further.

Even if pressure on the state banks does come from depositor withdrawals, there will not necessarily be a full-blown crisis, since the central bank will be able to issue currency to the state banks to meet withdrawals. This expansion of high-power money cannot be easily translated into a loss of foreign reserves because capital controls, which I support, remain in place and are likely to do so for the foreseeable future. The resulting expansion of high-power money will not have an impact on inflation because it represents a shift from bank deposits to cash, or from some banks to others, and not a shift to goods. In the current deflationary atmosphere, a run from bank deposits to goods would be stabilising. The government has the technical ability to accommodate shifts in bank deposit preferences, even a modest bank run, without risking exchange rate collapse or runaway inflation.

If the banking system is plagued by frequent bank runs, its role as a financial intermediary will be greatly reduced, and economic growth could suffer significantly. The real issue is not whether depositor shifts or a run on a bank could be accommodated, but how a banking crisis could be prevented from occurring in the first place. The government must keep the banks adequately capitalised at all times. 
Another reason for the banks to be recapitalised is that this will lower the lending rate, and hence spur capital formation. To see how NPLs raise lending rates, note that the cash-flow constraint that a bank (regardless of solvency) must meet in the absence of state subsidies, operating costs, and a reserve requirement is given by

$$
r_{D} D=r_{L}[D-N P L]
$$

where $r_{D}=$ deposit rate, $r_{L}=$ lending rate, and $D=$ amount of deposit.

This means that if an NPL equals one-third of deposits, then the lending rate has to be at least 50 per cent higher than the deposit rate. The significant implication, however, is that a new bank (domestic or foreign) can undercut the lending rate of the existing $S O B$ because it will not have any NPLs on its books. Since the government recapitalised the banks in 1998, and needs to do so again now, the important question is whether there are technical and political obstacles that can prevent China from implementing another round of bank recapitalisation. How many more rounds of bank recapitalisation can China afford without generating a fiscal crisis?

\section{HOW SERIOUS IS THE THREAT OF FISCAL INSOLVENCY?}

The prolonged use of loose fiscal policy carries two major risks. The first risk is low economic efficiency of state investment, especially of many infrastructure projects implemented in the last four years. Almost all these projects were implemented hurriedly, with some projects approved even before the feasibility reports were completed. In 1998 and 1999 there were frequent reports about the collapse of recently built bridges and roads. This risk of fiscal inefficiency has been confirmed by an internal study by the Ministry of Finance, which found that the amount of investment required to create one additional unit of GDP has increased significantly in recent years (Gao 2002).

The second, and possibly more serious, risk to fiscal management is fiscal sustainability. Proactive fiscal policy contributes to fiscal risks in two ways, directly by increasing both fiscal deficits and public debts, and indirectly by increasing the amount of NPLs through influencing banks' lending decisions. A higher debt-GDP ratio means more debt servicing in future periods, and this could require expenditure cuts to prevent an upward spiral of the debt-GDP ratio-a development that could convince financial markets that the state is resorting to the Ponzi scheme (or pyramid scheme) to finance its deficits. 
Fiscal sustainability lies at the heart of whether a banking crisis would actually occur. As long as the state is perceived as able and willing to bail out failing SOBs, depositors will retain their confidence in the SOBs, regardless of the actual state of their balance sheets. The stock of publicly acknowledged government debt is 16 per cent of GDP, and it is common to hear official assurances that current fiscal deficits of less than 3 per cent of GDP do not pose a problem for debt servicing by the state. Analytically, however, the correct measure of public debt should be the consolidated debt of the state sector, including at least some part of contingent liabilities (for example, foreign debts of SOEs and SOBs, and unfunded pension schemes in the SOE sector). If an analyst counts NPLs as contingent liabilities, then she is really computing what the public debt will be after one more round of bank recapitalisation. According to Fan (2003), consolidated public debt at the end of 2001 amounted to 72 per cent of GDP; according to Citigroup (2002), it could be as high as 115 per cent (Table 3.5). So, is China's present debt-GDP ratio too low or too high?

In 1995, central government debt-GDP ratios in Italy, Sweden and the United States were, respectively, 117.6 per cent, 70.8 per cent, and 50.5 per cent in $1995 .{ }^{19}$ So, if China undertakes its second bank recapitalisation, its public debt will still be within the range of advanced OECD countries that are not experiencing fiscal crises. However, two important points show that this finding is not optimistic.

First, the forthcoming recapitalisation of China's banks appears to be the last major one that the government could implement in the short term without risking the

Table 3.5 Contingent liabilities in China, end of 2001

\begin{tabular}{lcc} 
& RMB billion & $\begin{array}{c}\text { Per cent } \\
\text { of GDP }\end{array}$ \\
Accumulated public debts & 1,550 & 16.2 \\
Special T-bonds in 1998 for recapitalisation & 270 & 2.8 \\
Estimated costs for bank restructuring & 4,500 & 46.9 \\
Estimated costs for social security funds & 2,500 & 26.1 \\
Municipal government contingent debt & 700 & 7.3 \\
External debts & 1,500 & 15.6 \\
Total & 11,020 & 114.9 \\
& & \\
Note: This is an updated estimation based on new information available on both gaps in social \\
security funds and municipal government contingent debts for which the central government is \\
the guarantor. These were estimated on the basis of communication with government economists. \\
Source: Citigroup, 2002. Greater China Insights, 14 June. \\
\hline
\end{tabular}


stability of the domestic financial markets and its credit standing in the international financial markets. A third recapitalisation (since 1997) would push the debt-GDP ratio to over 150 per cent, well above the OECD norm.

Second, if China recapitalises the SOBs a second time, it will have to compromise the expansionary fiscal policy that has been keeping GDP growth above 7 per cent since 1997. This is because China raises much less state revenue (as a share of GDP) than the OECD countries, and hence has a much lower capacity to service its public debt. The revenue-GDP ratio was 16.2 per cent for China in 2001, 30 per cent for Italy in 1995, 38 per cent for Sweden in 1995, and 21 per cent for the United States in $1996 .^{20}$ China's additional debt service from the second bank recapitalisation will be about 1.5 to 2.5 per cent of GDP. ${ }^{21}$ If China increases tax collection or reduces infrastructure spending to cover this increased debt service, then this second recapitalisation of the SOBs will reduce the fiscal stimulus that has been keeping GDP growth rate above 7 per cent. Between these two options, expenditure reduction cannot be considered the less likely outcome, because in China's experience during the reform era frequent changes to the tax system have not been able to raise revenue significantly for sustained periods. The reason for the low revenue-GDP ratio could be that increasing tax collection is as much a political as an administrative challenge.

If the issue of fiscal sustainability is viewed in the broader context of debt dynamics, one might be tempted to be more optimistic about the present situation, and thus dismiss the existence of a trade-off between bank recapitalisation and fiscal stimulus. Such an optimistic assessment is based on the assumption that China's annual growth trend over the next decade and a half will continue to be at least 7 per cent, meaning that the high debt-GDP ratio of 115 per cent of today would be reduced over time by the high rate of output growth. There would be no need to cut back on the fiscal stimulus to service the additional debt from the new round of bank recapitalisation. China could just borrow more to cover the additional debt service, and wait for the economy to 'grow' out of its debt.

This optimism is based on the evolution of the debt-GDP ratio as given by

$$
d(\ln [D e b t / G D P]) / d t=r+p+b-y
$$

where $r=$ real interest rate on government debt; $p=$ primary fiscal deficit rate $=$ [state expenditure excluding debt service - state revenue]/GDP; $b=$ NPL creation rate $=$ [change in NPL in SOB] / GDP; and $y=$ trend growth rate of real GDP. 
For convenience, I assume y to be 8 per cent, and $p$ to be 2 per cent. (According to Deutsche Bank (2003), p was 1.8 per cent in 2001 and 2.2 per cent in 2002, and is likely to be 2.1 per cent in 2003.) One seemingly plausible estimate of the real interest rate $(r)$ is 4 per cent, obtained by combining the government bond rate on 25 March 2003 at .65 per cent, and a negative 1 per cent inflation. If we now add the unrealistic assumption of $b=0$ to this example, we see that $y$ exceeds the sum of $r$ and $p$ by 2 percentage points, implying that the debt-GDP ratio declines over time.

However, this safety margin of 2 percentage point for China's debt situation is based on the wrong assumption of $b=0$. The fact that China must now undertake another recapitalisation after 1998 to solve the problem of NPLs valued at 35 per cent of GDP suggests that $b=7$ per cent! If we make the assumption that the SOBs will be able to reduce the annual NPL creation rate (b) to 2 per cent of GDP after this second recapitalisation, can we reach the optimistic conclusion that China can simply grow out of its debt without having to face the trade-off between bank recapitalisation and fiscal stimulus?

This optimistic conclusion is also dependent on two other highly unrealistic assumptions

- that there will not be another round of bank recapitalisation in the future-an assumption about state banks that has been falsified not only by international experience but also by China's own experience since 1998

- that China can promote the development of its financial sector without freeing state-set interest rates.

Because the real interest rate of 4 per cent (used above) is the product of interest rate ceilings, the shadow interest rate is likely to be substantially higher. As China is a capital-shortage country, the real rate of return on physical capital in China must be higher than in the United States, suggesting that it is likely to be over 15 per cent. Thus, if there were an efficient government bond market in China today, the lower boundary of the real government bond rate could be at least 6 per cent.2? This two percentage point rise in the real interest rate is made more plausible by the fact that the state would have to issue new bank recapitalisation bonds that amount to 40 per cent of GDP. In short, under interest rate liberalisation and with $b=2$ per cent, the primary fiscal deficit $(p)$ would have to be cut from two per cent to zero, that is, the fiscal stimulus would have to be eliminated in order for the debt-GDP ratio not to spiral uncontrollably upward. 
As international experience shows interest rate liberalisation to be crucial to the increasing sophistication of financial markets, I really see no reason to feel assured about the sustainability of China's fiscal situation. The lesson from this debt dynamics exercise is that we have to be very cautious about a benign scenario for China's fiscal situation. Even with the optimistic assumption that NPLs equal two per cent of GDP, China has no margin of safety to ensure fiscal solvency. There is a trade-off between maintaining its fiscal stimulus to reduce unemployment and liberalising interest rates to promote financial sector development.

In summary, China's consolidated debt-GDP ratio would be relatively high by international standards after a second bank recapitalisation, while its revenue-GDP ratio would remain relatively low. The threat to the stability of China's financial markets is fiscal sustainability, and the threat to fiscal sustainability is successive rounds of bank recapitalisation. This precarious outcome is a systemic feature of the current banking system, a relic from the era when central planning was the preferred engine of economic growth. We cannot attribute the creation of NPLs entirely to the SOBS; their chief customers, the SOEs, deserve an equal share of the blame. The fact is that the problem of NPLs cannot be solved unless the SOE problem is also solved. ${ }^{23}$

\section{MACROECONOMIC AND SOCIAL INSTABILITY FROM THE STATE ENTERPRISE SECTOR}

The inflationary problem generated by the traditionally biggest macroeconomic destabiliser (the SOE sector) still exists. If anything, the SOE sector in 2003 has not only become a potential source of more macroeconomic instability, but also emerged as a source of socio-political instability. To see the origin of these negative developments, we review the Fan and Woo (1996) argument that the reform strategy for the SOE sector during 1978-93 was inherently inflationary. ${ }^{24}$

The crux of the 1978-93 SOE reform strategy was to transfer decision-making power from the industrial bureaus to the state enterprises. The increased operational autonomy of the SOEs reduced the ability of the industrial bureaus to monitor the financial situation within the SOEs, and hence created the incentive for SOEs to greatly increase their demand for investment funds. The reduction in bureaucratic oversight of SOEs in a soft-budget environment allowed the SOEs to use creative accounting to privatise profits from good investment projects, and to receive state subsidies to cover losses from bad investment projects. Until about 1996, SOEs 
were generally able to satisfy their large appetite for investment because the local governments, in the interest of local development, inevitably lobbied local branches of the state banks to grant the SOEs' applications for investment loans. The evidence is overwhelming that local bank branches, at least until 1995, were unable to resist the demand for easy money. ${ }^{25}$

Losses at SOEs exploded after 1992 with the fall of the former Soviet Union, when many Chinese SOE managers saw the same fate for China and concluded that this was their last chance to steal. SOE losses skyrocketed, even though GDP grew in the range of 10-14 per cent annually in the 1992-95 period. By 1995, it was common to summarise the SOE situation in terms of one-third losing money and another one-third making no money. From the vantage point of 2003 , it seems that continued inefficiency and de facto asset-stripping and embezzlement of profits by managers and workers were the primary causes of the general decline in SOE profits, with the latter being the more important. Devolution of financial decisionmaking power to the SOEs, and steady reduction in discrimination against the private sector have made it increasingly easy for the managers to transfer state assets to themselves. Of the 327 cases of embezzlement, bribery and misuse of public funds that were tried in Beijing in 1999, '76 per cent took place in SOEs'. ${ }^{26}$

Increasing public outrage over the inequity of the informal privatisation of the SOE sector is well captured by He Qinglian who wrote that the SOE reform has amounted to

a process in which power-holders and their hangers-on plundered public wealth. The primary target of their plunder was state property that had been accumulated from forty years of the people's sweat, and their primary means of plunder was political power. ${ }^{27}$

By 1994, the Chinese leadership had recognised the increasingly serious economic and political problems created by the principal-agent problem innate in its decentralising reforms of market socialism. thus it announced that the clarification of property rights of SOEs would be added to the SOE reform program. In July 1997, the Communist Party of China (CPC) publicly committed to convert most of the SOEs to publicly traded shareholding corporations-a form of industrial organisation that originated in capitalist economies. Employment growth in the industrial sector (Table 3.1) fell from 2.1 per cent in 1997 to 0.3 per cent in 1998, then became negative in the following years. The restructuring of state manufacturing industries had occurred even earlier, in 1996. 
The state's decision to accelerate diversification of the ownership structure of the SOEs in 1997 was a bold move, because experiences with mass privatisation in Eastern Europe and the former Soviet Union (EEFSU) demonstrated that the task was extremely difficult and outcomes consistently fell below initial expectations. In Russia, 'loans-for-shares' privatisation transferred the country's enormous mineral wealth to a group of oligarchs, and the weak administrative and legal structures allowed many managers to take effective control of the privatised firms and loot them instead of improving their operations. Furthermore, the EEFSU experiences warn that mass privatisation is an exceedingly dangerous business politically, since it generates great amounts of rent and the resulting corruption inevitably affects government. The governments of both Vaclav Klaus and Boris Yeltsin were affected in this way.

Privatisation has been going forward in China (albeit with occasional stops) for two main reasons. The first reason comes from John Nellis (1999), who points out that 'governments that botch privatisation are equally likely to botch the management of state-owned firms'. The answer is not to avoid privatisation but to implement more careful privatisation: governments in transition economies should 'push ahead, more slowly, with case-by-case and tender privatisations, in cooperation with the international assistance community, in hopes of producing some success stories that will lead by example.'

The second reason lies in the fact that delaying privatisation would be costly to China's government politically. The maintenance of the status quo has become increasingly difficult because SOE managers in China know from the EEFSU experience that they are in an endgame situation. Widespread spontaneous privatisation by SOE managers could create grave social instability.

The solution to the SOE problem in China is not privatisation per se, but a transparent, legal privatisation process that society at large can accept. Because an adequate privatisation program must compensate retired and laid-off workers, permit takeover by core investors, and respect the rights of minority shareholders, it is important that legal reforms be carried out simultaneously. Only with a transparent, equitable privatisation process overseen by an adequate legal framework would China be likely to avoid a state-created Russian-style kleptoklatura.

Recently, there has been some questioning about whether the case for privatisation has been overstated. ${ }^{28}$ When Zhu Rongji was designated the new premier in 1997, 
he announced that he would solve the SOE problem in three years. In 2000, he declared victory on the SOE front when the profits of the industrial SOEs leaped from 53 billion yuan in 1998 to 241 billion. Zhou and Wang (2002) quantified the sources of the financial turnaround, and found that

- the lower interest rate in 2000 increased profits by 52 billion yuan (28 per cent of the increase in SOE profits)

- the higher oil prices boosted overall SOE profits by 79 billion yuan because almost all oil companies are state-owned (42 per cent of the increase) $)^{29}$

- the conversion of the bank loans of SOEs into equities held by state asset management companies raised profits by 10 billion yuan ( 5 per cent of the increase).

About 75 per cent of the increase in the profits of industrial SOEs in the 19982000 period was not due to actions taken within these enterprises but to external factors. When Zhou and Wang (2002) calculated the profit rate after deducting the profits from the more favourable external environment, they found profits had increased from 0.7 per cent in 1998 to 1.2 per cent in 2000 for the SOE sector, and from 2.8 per cent to 4.8 per cent for the non-SOE sector. Despite the recent good news on SOE profitability, the fact remains that the SOE sector still lags considerably behind the non-SOE sector in efficiency.

While the recent rise in profits gives some breathing space, the capacity of SOES to 'dissipate rents' through high payments to managers and workers, if not illegal transfer of assets, should remain clearly in the policymakers' minds, otherwise any gains could be squandered, if not reversed, in a relatively short period of time. It is important for China to replace uncontrolled (and uncontrollable) asset stripping in the SOE sector with transparent and equitable privatisation in order to improve macroeconomic stability and defuse socio-political instability.

\section{CONCLUSION}

I have argued that China's dysfunctional financial system has imparted a deflationary bias to the economy and made China a capital-exporting country by constraining the growth of aggregate demand to a lower level than the growth of aggregate supply. The government has been actively trying to neutralise deflation through an aggressive fiscal policy. I recommend that it should now expand its investment program to incorporate large import-intensive infrastructure projects so that the trade surplus can be reduced as well. This move would be a better alternative to the appreciation 
of the RMB as suggested by China's foreign friends. The additional infrastructure construction would create jobs, relieve production bottlenecks, and, on top of all this, preserve employment in China's export-oriented sectors. However, the most efficient solution is for private investment rather than public investment to recycle the pool of private savings back into the economy. The key to eradicating the deflation bias and the tendency towards current account surplus lies in establishing an efficient financial intermediation mechanism.

If the Chinese government decides to keep the SOBs as the dominant financial intermediation mechanism, there is really little to be gained by recapitalising the SOBs. This suggests that an effective way to slow the pace of NPL creation in an SOB-dominated financial system and to sustain the fiscal situation might be to keep the NPLs on the books of the SOBs, and 'the financial status of these loans should be constantly watched and openly discussed' in the public media (Fan 1993).

For Fan Gang's suggestion to work, it is necessary that foreign banks (which by 2008 will face no more restrictions than Chinese banks) will not expand aggressively out of the big coastal cities. If the foreign banks do expand rapidly, then their lower costs from the absence of NPLs will allow them to charge lower lending rates than the SOBs. This will eliminate the SOBs, because WTO regulations make it illegal for the government to subsidise SOBs against foreign competition. Fan Gang's method should work for 7-10 years because only HSBC and Citibank are likely to expand their banking network actively in China in the next decade, and even then only in the main coastal provinces.

The most important priority for financial sector reform is the establishment and growth of competitive domestic banks. As China is required by its WTO accession agreement to allow foreign banks to compete against its SOBs on an equal basis by 2007 , it would be ridiculous not to allow the formation of truly private banks of domestic origin. There is no reason to favour foreign private banks over domestic private banks, and no reason why China should not allow its best financial minds compete with the best foreign financial minds. I therefore recommend that, after recapitalisation of the big four state banks, at least two be broken into regional banks, and that the majority of these regional banks be privatised..$^{30}$ At the same time, the laws on the establishment of new banks should be loosened, and interest rates deregulated. However, it is crucial that the speed of financial sector liberalisation should proceed no faster than the development of the financial regulatory ability of the state. Even then, the danger of substituting financial crash for financial repression 
is still a real one. A modern financial system requires a modern system of financial supervision and prudential regulation for its proper functioning.

It would be a good idea to sell a few of the regional state banks to foreign banks. This would facilitate the transfer of modern banking technology to Chinese banks. The more local staff foreign bankers train, the larger will be the pool of future managers for Chinese-owned banks. An accelerated process of promoting the growth of sound domestic private financial institutions and allowing the entry of foreign financial institutions would certainly shorten the time it would take for Shanghai to assume its rightful place among the major international financial centres, and to contribute to more efficient intermediation in the world's savings.

Entry of Western banks into China's financial markets is not the same as liberalisation of the capital account in the balance of payments. China would not be well served by a rapid opening of the capital account, since that could subject China to the same rapid swings of short-term capital that shattered the economies of Southeast Asia and Latin America. Capital account opening should also proceed gradually, because it must be accompanied by sophisticated financial market regulation, something that is clearly not in place now. Foreign banks could become conduits for large-scale capital flight, or for rapid swings in short-term lending and repayments, or facilitators of bank runs (in which depositors do not merely switch banks, or switch from domestic banks to domestic currency, but actually switch from domestic deposits to foreign assets).

Besides successive rounds of bank capitalisation, other shocks could also undermine the fiscal sustainability of the state. One such shock would be an AIDS pandemic that would necessitate increased state spending on public health; another would be massive construction to offset a major ecological disaster and significant climatic changes (for example, water shortages in the northern provinces, alternative energy systems to traditional methods of burning coal). The SARS epidemic is an important reminder that macroeconomic stability depends on more than just traditional shocks. The economic costs of SARS have been greatly magnified by an inadequate public health system and by structural weaknesses in information dissemination. China's new leaders should take a more comprehensive view of economic growth and the implications of socio-political influences on macroeconomic management.

There can be no greater confirmation of China's determination to make the private sector its new growth engine than the tenacity with which it pursued WTO membership. 
The WTO is limited to private market economies, and it requires that the economic institutions of its members converge within a specified period to some broadly defined norms compatible with the main forms of market capitalism. The challenge to China's new leaders is the proper management of institutional convergence in the wake of low, or negative, employment growth in the industrial sector in the four years leading up to WTO accession. ${ }^{31}$ The fiscal burden of installing the new economic growth engine is a heavy one, and my analysis shows that China can just afford it. The absence of a safety margin in fiscal management highlights the importance of competent economic management. This does exist in China, however the absence of a safety margin also highlights the importance of continued good luck. While the many reform tasks ahead are challenging, we take heart from the fact that during 1979-2002 many other challenges were faced and overcome.

\section{NOTES}

1 This chapter emerged from an ongoing project on Economic Growth in China conducted by the East Asian Program of the Center for Globalization and Sustainable Development at Columbia University. I am grateful to Fan Gang, He Liping, Huang Yiping, and Yu Yongding for sharing their insightful analyses on the Chinese economy with me. I am deeply indebted to the Citigroup office in Hong Kong for assistance in data compilation.

2 Employers in SARS-affected areas were also ordered 'not to lay off workers'. See 'China tries to stanch economic fallout as disease, worry spread: emergency policies boost public spending', Washington Post, 9 May 2003.

3 If realised, the official urban employment rate would rise from 4 per cent at the end of 2002 to 4.2 per cent at the end of 2003. Data are from 'Economy not working hard enough', South China Morning Post, 16 August 2003. However, it is well known that the official data on urban unemployment tend to understate the problem. When the official urban unemployment rate was 3.6 per cent in June 2002, a Chinese Academy of Social Studies report estimated the actual urban unemployment rate to be 7 per cent, and Liu Wei of Beijing University estimated it to be 14.6 per cent. See 'China jobless figures enter danger zone', Straits Times, 15 June 2002.

4 'Budget and job woes threaten stability', South China Morning Post, 19 December 2002.

5 For example, 'Snow calls on Beijing to let currency float', Financial Times, 2 September 2003.

' See, for example, 'Behind the debate over China's currency', Barrons, 28 July 2003; 'US job losses blamed on China's currency', The New York Times, 26 August 2003; and 'Economic ministers discuss Chinese currency', Pacific Business News, 23 July 2003. 
7 The inflation rate is calculated from the retail price index (RPI). The average inflation rate according to the consumer price index (CPI) (available from 1985) is 0.6 per cent for the first of 2003 and 7.7 per cent for 1985-2002. CPI is broader than RPI because it also covers services and housing. The 2003 GDP growth rate is from 'National economy faces a string of challenges', China Daily, 26 August 2003.

8 This interpretation of China's economic performance after 1978 is elaborated in Woo (1999) and Woo (2001).

9 Graphing the growth-inflation relationship, with the inflation rate on the $y$-axis, the relationship is a vertical line at each endpoint of the range. This does not mean that the positive portion of the graph could be exploitable for macrostabilisation, since changes in expectations could shift it up and down very quickly.

${ }^{10}$ Citigroup (2003) has projected the budget deficit to be 2.8 per cent in 2003 . The scale of the fiscal stimulus has evoked comparisons with the New Deal, and provoked catchy headlines in the media, for example, 'China gambles on big projects for its stability', New York Times, 13 January 2003, and 'Public spending explodes', Far Eastern Economic Review, 30 January 2003.

$"$ Keynes coined these both terms. Strictly speaking, the Chinese characterisation of the liquidity trap as a 'shrinking money multiplier' does not correspond to Keynes's original meaning. Keynes was referring to the situation where the interest rate would not fall despite the addition of reserves because of the predominant expectation held by investors that the interest rate would rise soon. In brief, the difference is 'the shrinking money multiplier' versus the non-falling interest rate.'

12 For example, during the SARS period, the banks faced intense pressure from the central bank to extend credit.

13 The Chinese government has sought to increase bank lending to private individuals by encouraging banks to establish mortgage loans, which are perceived as less risky because of their seemingly fully collateralised nature. While it is still early to tell, it appears that the enthusiasm for real estate lending in 2002 might have started a speculative bubble in that sector.

${ }_{14}$ Woo (2000) presents a proposal of how to meet investment financing needs in rural China.

15 It is important to note that this equation applies only to China's total trade surplus, not to any bilateral trade surplus between China and another country. The equation in standard textbook notation is

$C A=(T-G)+(S-1)$.

${ }^{16}$ Of course, just as the current account outcome is the product of the three terms in the equation, multi-variable causation also applies to the savings outcome, for example, demographic features, 
expected future income growth. Our discussion has concentrated on how one of these variables, the type of financial intermediation mechanism, can affect the savings rate.

17 It appears that the AMCs have started by concentrating on the NPLs with the best prospect for recovery', and that the 'average cash-recovery rate' on the small amount processed by June 2002 is 21 per cent. This recovery rate is expected to drop substantially when the more difficult loans are processed. See 'On the road to ruin', Far Eastern Economic Review, 14 November 2002.

18 The US ratio is for 1996. Ratios were constructed from the IMF's International Financial Statistics.

19. The revenue-GDP ratio for China is from Deutsche Bank (2002) which estimated that it will rise to 16.4 per cent in 2002 and 16.6 per cent in 2003. Debt-GDP and revenue-GDP ratios for other countries are from the IMF database.

2 This assumes a bond rate of four-six per cent-an assumption discussed in the next paragraph.

21 According to Solow (1991), the stylised fact for the real interest rate in the United States is that it is $5-6$ per cent.

22 See Wen (2003) for a recent analysis of the joint reform of the SOBs and SOES.

$\approx$ See Huang et al. (1999) for an account of the failure of SOE reform.

${ }^{24}$ The institutional reforms of the central bank and the state banks implemented in July 1993 as part of an austerity campaign have not been successful in changing the situation. Chen Yuan (1996), Deputy Governor of the Central Bank, reported that 'the enthusiasm for economic growth in some localities is so strong that it is very difficult to stop completely excessive investment financed through forced bank credit' (emphasis added).

25 'Judicial attention to SOEs pledged,' China Daily, 19 February 2000.

${ }^{26}$ He Qinglian, Zhongguo de Xianjing, (China's Pitfall), Mingjing Chubanshe, Hong Kong. The translated quote is from Liu Binyan and Perry Link, 'China: the great backward?', The New York Review of Books, 8 October 1998:19.

27 See Nolan and Wang (1999) for a recent assertion of a turnaround in SOE performance.

28 This estimate has taken into account the additional production cost of the non-oil SOEs.

29 Partial recapitalisation is likely to occur soon, and it is likely that the target will be the reduction of the NPL ratio from 35 per cent to 15 per cent. The cost is estimated to range from 700 million yuan to 1 trillion yuan (7 to 10 per cent of GDP)--see 'Massive bailout proposed for banks', South China Morning Post, 26 August 2003.

30 Recent insightful discussions on the conditions for meeting this challenge successfully, and on the impact of WTO accession on the Chinese economy can be found in Lu et al. (2003), Song (2002a), Song (2002b), and Yu (2003). 


\section{REFERENCES}

Chen, Y., 1996. 'Opening remarks', in M. Guitian and R. Mundell (eds), Inflation_and Growth in China, International Monetary Fund, Washington, DC:23-28.

Citigroup, 2002. Greater China Insights, Citigroup, 14 June.

-, 2003. China Economics, Citigroup, 6 March.

Deutsche Bank, 2002. Emerging Markets Monthly, Deutsche Bank, 4 September. - , 2003. Emerging Markets Monthly, Deutsche Bank, 6 March.

Fan, G., 2003. 'China's NPLs and national comprehensive liability', Asian Economic Papers, 2(1):145-52.

- and Woo, W.T., 1996. 'State enterprise reform as a source of macroeconomic instability', Asian Economic Journal, 10(3):207-24.

Gao, J., 2002. China's financial system and financial market reform:WTO participation and its challenge to China's financial sector, Paper presented at the Citigroup Investors' Seminar, Shanghai, 8 May.

Huang, Y, 2003. 'What will drive China's growth?', Macro China, Citigroup, 13 June.

—-, Woo, W.T. and Duncan, R., 1999. 'Understanding the decline of China's state sector', MOCT-MOST: economic policy in transitional economies, 9(1):1-15.

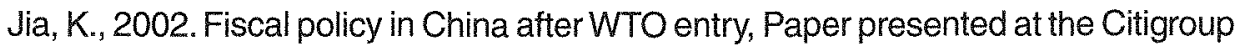
Investors' Seminars, Shanghai, 8 May.

Kuroda, $H$. and Kawai, M., 2002. 'Time for a switch to global reflation', Financial Times, 1 December.

Liu, L.Y. and Woo, W.T., 1994. 'Saving behavior under imperfect financial markets and the current account consequences', Economic Journal, 104(424):512-27.

Lu, D., Wen, G.J. and Zhou, H. (eds.), 2003. China's Economic Globalization through the WTO, Ashgate, Aldershot.

Nellis, J., 1999. Time to Rethink Privatisation in Transition Economies?, Discussion Paper No. 38, International Finance Corporation, World Bank.

Nolan, P. and Wang, X., 1999. 'Beyond privatization: institutional innovation and growth in China's large state-owned enterprises', World Development, 27(1):169200.

Solow, R., 1991. 'Sustainability: an economist's perspective', the 18th J. Seward Johnson Lecture to the Marine Policy Center, Woods Hole Oceanographic Institution. Reprinted in R.N. Stavins, 2000. Economics of the Environment: selected readings, 4th edition, W.W. Norton, New York:131-38. 
Song, L., 2002a. 'Conditions and prospects for sustaining China's economic growth', in L. Song (ed.), Dilemmas of China's Growth in the Twenty-First Century, Asia Pacific Press, Canberra: $1-10$.

- (ed.), 2002b. Dilemmas of China's Growth in the Twenty-First Century, Asia Pacific Press, Canberra, Australia.

State Statistical Bureau, various years. Zhongguo Tongji Nianjian [China Statistical Yearbook], Zhongguo Tongji Chubanshe, Beijing.

Wen, M., 2003. Further reform of SOEs and state banks, Paper presented at the China Update Conference, The Australian National University, Canberra, 25 September.

Williamson, J., 1988. 'Comments on Reflections on Development, in G. Ranis and T. P. Schultz (eds), The State of Development Economics: progress and perspectives, Blackwell, Oxford and New York:24-30.

Woo, W.T., 1999. 'The real reasons for China's growth', The China Journal, 41(January):115-37.

- 2000. 'Improving access to credit in rural China', in B. Chen, J.K. Dietrich and Y. Feng (eds), Financial Market Reform in China: progress, problems and prospects, Westview Press, Boulder, Colorado:321-45.

- 2001. 'Recent claims of China's economic exceptionalism: reflections inspired by WTO accession', China Economic Review, 12(2-3):107-36.

- and Liu, L.Y., 1995. 'Investment-motivated saving and current account malaise', Asia-Pacific Economic Review, 1(2):55-68.

Yu, Y., 2003. Fiscal stability and the road to prosperity, Institute for World Economics and Politics, Chinese Academy of Social Sciences, Beijing (unpublished).

Zhou, F. and Wang, X., 2002. The Way of State-Owned Enterprise Reform in China, National Economic Research Institute, Beijing, China. 